\title{
Assessing Student Engagement in Online Programmes: Using Learning Design and Learning Analytics
}

\author{
Maria Toro-Troconis ${ }^{1}$, Jesse Alexander ${ }^{2} \&$ Manuel Frutos-Perez ${ }^{3}$ \\ ${ }^{1}$ Cambridge Education Group Digital, Head of Academic Research and Quality, UK \\ ${ }^{2}$ Institute of Photography, Falmouth University, UK \\ ${ }^{3}$ Cambridge Education Group Digital, Business Development Director, UK \\ Correspondence: Maria Toro-Troconis, Cambridge Education Group Digital, UK. E-mail: mtroconis@ceg-uk.com
}

Received: September 20, 2019

Accepted: October 15, 2019

Online Published: October 16, 2019

doi:10.5430/ijhe.v8n6p171

URL: https://doi.org/10.5430/ijhe.v8n6p171

\begin{abstract}
This paper presents the learning design framework used in the design of the Online MA in Photography at Falmouth University. It discusses the importance of evaluating the success of online learning programmes by analysing learning analytics and student feedback within the overall pedagogic context and design of the programme. Linear regression analysis was used to analyse the engagement of three cohorts of students that completed four modules of the Online MA Photography $(n=33)$ with over 80,000 entries in the dataset. The research explored student engagement with online content that promoted low-order cognitive skills (i.e. watching videos, reading materials and listening to podcasts) as well as high-order cognitive skills (i.e. participating in online forums and webinars). The results suggest there is weak evidence of an association between average overall mark in all modules and the level of engagement with self-directed content $(\mathrm{P}=0.0187)$. There is also weak evidence of an association between average overall mark in all modules and the level of engagement in collaborative activities $(\mathrm{P}<0.0528)$. Three major themes emerged from the focus group 1) weekly forums and webinars, 2) self-directed learning materials and 3) learning design and support. Online learning was acceptable and convenient to postgraduate students. These findings are discussed further in the paper as potential predictors of student performance in online programmes.
\end{abstract}

Keywords: online learning, learning design, learning analytics, student engagement

\section{Introduction}

According to Bates (2005), online learning represents the convergence of three main advances and trends that have fundamentally contributed to shape modern society in the XXI Century: learning in non-traditional settings; widespread access to computing devices and telecommunication technologies.

Distance learning has a long and well-established tradition as a delivery method in higher education (Anderson \& Dron 2010). The University of London has been offering distance learning degrees since 1858. Distance learning became an alternative to traditional campus-based courses, opening up qualification routes to learners who otherwise would not have had access to higher education (Keegan, 2013). The trade-off that Distance Learning offered was access in exchange for losing cohort interaction and reduced institutional support (Holmberg, 2005). Decades of development of good practice followed and culminated in 1969 with the creation of the first University in the UK to only offer distance learning courses: The Open University.

Distance learning initiatives have always been at the forefront of incorporating technology to facilitate the delivery of the courses in order to maximise learner engagement and minimise access barriers (Garrison, 1985). This included radio and tv broadcasts, audio and video tapes, software, CDs, CD-ROMs and DVDs.

The success of distance learning institutions (by 2012 there were already 400,000 distance learners enrolled on courses validated by UK Universities) coupled with the evolving needs of modern workforces sparked a trend that it is still increasing today in the number of learners who access learning via non-traditional settings, i.e. away from classrooms (Mayer, 2019). Lifelong learning is no longer just a vocational endeavor, but a necessity for populations who have much longer working lives and a working environment that evolves at pace.

The invention of the World Wide Web by Sir Tim Berners-Lee in 1989 was a watershed moment for the way in which human beings are able to communicate and interact with each other at a distance. Telecommunication 
technologies have since evolved at rapid pace in their reach, accessibility and complexity of the interactions that they are able to facilitate (Zhang \& Nunamaker 2003). Those technologies have become involved in almost everything we do, and learning has been no different. It has been particularly acute in distance learning as Internet technologies have rapidly supplanted all other technologies as delivery and communication facilitators (Harasim, 2017). Distance is no longer a defining characteristic or this mode of delivery, as those technologies have intrinsic immediacy and reach. This method of delivery is now more accurately coined as Online Learning (Stephenson, 2018).

The diverse nature of lifelong learners and their needs for short and fast-paced skills development, in combination with the democratisation of knowledge instigated by the Internet precluded the emergence of MOOCs - Massive Open Online Courses (De Freitas et al., 2015). MOOCs are short online courses that openly recruit learners from any location. MOOCs cover a multitude of topics, often quite specific, and don't require learners to engage according to a particular schedule, but they enable asynchronous learner communication across their large and diverse cohorts (Wong et al., 2018). This flexibility, and the open recruitment has made them very popular (Roll et al., 2018). The completion rates of MOOCs tend to be quite low as often learners just engage to get what they need in terms of learning something very specific (Jung \& Lee, 2018).

The good practice developed over decades in the distance learning field has converged with the relevance, currency and interaction offered by MOOCs, and has seen the development of a new breed of online full degree programmes that are cohort-based and taught remotely (Taylor $2001 \&$ Bonk et al, 2005). These programmes combine the most effective elements of classroom-based learning, distance learning and online learning: delivering and educational experience that is active, flexible, fully supported and crucially that fosters group learning across dispersed cohorts (Simpson, 2018).

This new delivery method: fully supported active online learning, is proving to be able to deliver very high retention and attainment rates (Panigrahi et al., 2018), and it is tapping into a very significant rise in demand for high quality tertiary education around the world. Global demand for post-secondary education is expected to rise from 165 million in 2013 to 263 million by 2025:

In 1970, there were only 28.5 million students in tertiary education worldwide. In 2000, the number had grown to almost 100 million students... As of 2012, there were 196 million students in tertiary education worldwide... Projections made by the UNESCO Institute for Statistics expect the global student population in tertiary education to expand to 263 million students in 2025. (UN, 2015)

This growth is going to be largely concentrated in emerging economies. The global middle class is expected to grow to 4.9 billion by 2030 , of which Asia will account for $66 \%$ - and these 3.2 billion people will demand higher quality public services. India is expected to see a huge increase in tertiary students, from 34 million in 2015 to over 70 million in 2030. In China, the number is expected to increase from 40 to 55 million. Brazil will have a smaller increase, but still substantial, rising from 7 million to 10 million over the same period. (Citigroup, 2017)

According to (Universities UK, 2018):

"Many higher education institutions report that they had invested, or were aiming to invest, in online provision aimed primarily at learners in employment seeking to enhance their careers.

In 2016-17, online learning made up 8\% of all provision at UK higher education institutions, with The Open University accounting for 65\% of all online learning, and other institutions $35 \%$. The number of UK higher education institutions offering online provision has increased from 102 in 2010-11 to 117 in 2016-17." (Universities UK, 2018:14)

There is no doubt the delivery of online education in Higher Education continues to grow, as well as the need to understand how to effectively design and deliver online programmes to ensure engagement and learning gains. A series of factors such as changing perceptions of the quality of online education and access and affordability of technology, have been identified as major contributors to the increased popularity of online education (Means et al., 2014).

Student engagement in educational activities has been described as the strongest predictor of students' learning and personal development in several studies (Kuh, 2001; Astin, 1993; Pascarella and Terenzini, 2005). Therefore, the exploration and understanding of how learning environments and learning design models have an effect on student engagement can inform the implementation of online programmes (Kuh, 2001; Rienties and Toetenel, 2016 and Toetene \& Rienties, 2016). 
According to Robinson and Hullinger (2008), the use of asynchronous technology tools promotes reflection leading to higher-order thinking. At the same time, Thurmond and Wambach (2004) found that engagement in online programmes increase the need for students to work collaboratively. Kent et al. (2016) also found that more interactivity and engagement with online discussion boards are related to higher course performance and a primary predictor for academic retention according to Rienties and Toetenel (2016).

Cabrera et at., 2002 discusses how interactions with peers in a collaborative learning environment is an important element of student engagement. At the same time, Ormrod (2011); Pascarella and Terenzini (2005) and Dumford and Miller (2018), discuss how activities that promote higher-order thinking and reflection can increase content knowledge and are linked to several aspects of achievement and success.

In the current study, we report students'engagement and views of an online programme taken as part of the Online MA Photography Programme at Falmouth University. Staff were interested in evaluating the learning design model used in the design and delivery of the modules assessing student engagement with different learning activities and overall pass marks.

Qualitative and quantitative studies were carried out to assess students' perceptions and engagement of the online programme and of online learning in general. The aims of the study were to address the following questions:

1. What factors optimise students' engagement with online learning?

2. How do students perceive postgraduate online learning?

\section{Learning Analytics and Learning Design}

The CEG Learning Design Framework has been used to guide and support academics in the design and development of weekly online learning materials for the Online MA Photography. The pedagogic composition of this framework is based on the Course Design Sprint Framework (CoDesignS, 2019) developed at the University of Liverpool and the Blended Learning Design Framework (BLENDT) developed at Imperial College London (Morton et al., 2016; Toro-Troconis et al., 2016; Toro-Troconis \& Aleksiev, 2018).

The first phase in the application of the pedagogic framework makes use of the learning domains (psychomotor, cognitive and affective), in order to allocate and classify the learning outcomes required within the specific learning activities. According to the framework, the more focused the learning outcomes are on developing attitude and high-order cognitive knowledge (conceptual and metacognitive), the more the learning activities fit a collaborative approach. The more focused the learning outcomes are on skills development as well as on low-end cognitive skills (factual and procedural knowledge), the more the learning activity can fit a self-directed learning approach (Bloom et al., 1956; Morton et al., 2016; Toro-Troconis, 2015).

The second phase in the application of the framework guides the design of learning activities for each of the learning outcomes identified previously, following the learning types suggested by Laurillard (2012): acquisition, enquiry, practice, production, discussion and collaboration.

The final phase distributes the learning types throughout the week following the 70:20:10 model in order to assess the balance of learning experience (Jennings, 2013; Lombardo \& Eichinger, 1996). According to the framework, on average, $10 \%$ of the time should be dedicated to acquisition, $20 \%$ of the time should be focused on discussion and collaboration and $70 \%$ of the time should focus on a combination of enquiry, practice and production activities (Morton, et al. 2016; CoDesignS, 2019).

The MA in Photography has been designed following this framework with learning outcomes focusing on developing attitude and high-order cognitive skills being delivered using online collaborative formats such as forums and webinars. At the same time, learning outcomes focusing on low-end cognitive skills, being developed using self-directed online learning materials such as videos, podcasts and readings.

Figure 1 shows how weekly learning activities were designed following those principles in a 5 step structure combining different learning types. The first step was the introduction to the week which provided an overview of the weekly topic often in a video format followed by a discussion - a question or idea posed by the module leader to encourage debate and gather students' initial ideas. The second step: guided practice was usually delivered in a self-directed format (video presentation, podcasts, interview format or interactive self-directed learning activities).

The third step presented a challenge activity in which students were asked to respond to a challenge related to the learning material of that week (the challenge may involve the production of an online artefact: image, video or document and discussions via the forum). The fourth step: reflection, provided the opportunity to reflect upon the ideas raised in the week and for learners to highlight any areas for clarification. Finally, the fifth step: webinar, 
provided the opportunity to communicate synchronously with tutors and peers providing an opportunity to share work for peer/staff review or simply an opportunity to reflect on weekly learning materials.

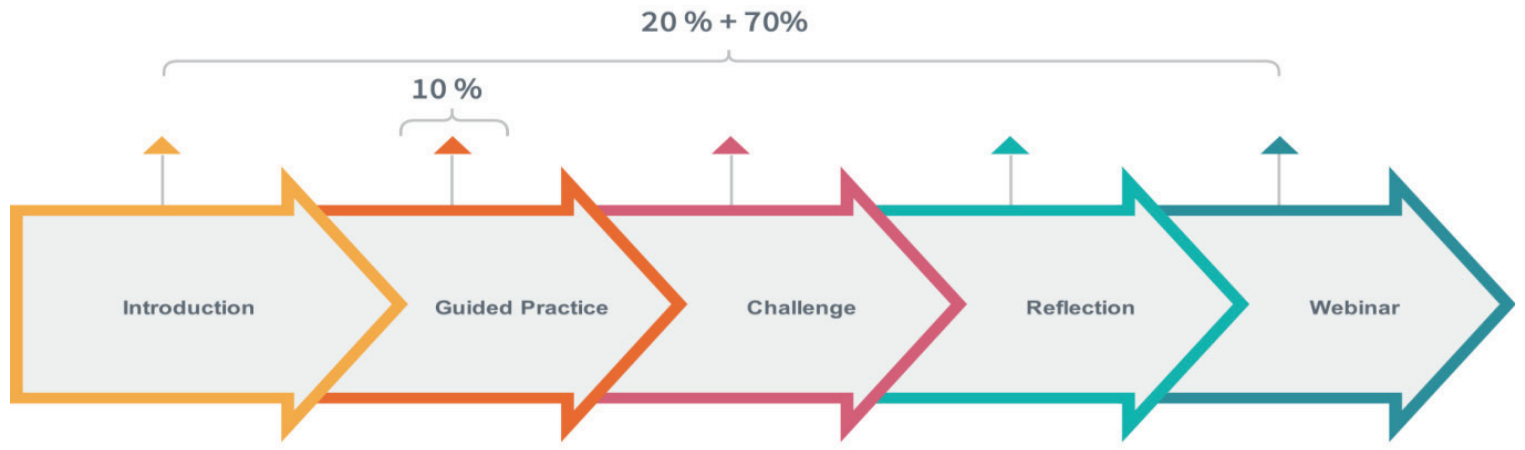

Figure 1. Learning design overview of the Photography modules based on the CEG Pedagogic Framework

The adoption of learning technologies, such as Virtual Learning Environments (VLEs), has had a major impact on the way learning data can be obtained. The resulting learning datasets provide opportunities for identifying indicators of teaching quality and assessment of student learning and engagement. This area of applied research has been defined as learning analytics (Lockyer et al., 2013).

"Learning analytics (LA) has drawn the attention of academics, researchers and administrators. This interest is motivated by the need to better understand teaching, learning, "intelligent content," and personalization and adaptation." Siemens (2013: 1380)

The field of learning design started to emerge in the early 2000s when academics and educational developers saw the potential of recording online examples of good educational practice. Learning design was then conceived as the mechanism to provide a general pedagogical picture of the intended unit of study and its planned pedagogic actions (Masterman, 2009; Lockyer et al., 2013).

As described recently by several authors (Dalziel et al., 2016), the first body of work in this area was initiated by Rob Koper at the Open University of the Netherlands with his work on the Educational Modelling Language (EML), which was subsequently adopted as the basis for the IMS Learning Design technical specification in 2003 (IMS GLC, 2003; Koper, 2001). The second main body of research was the work carried out in Higher Education in the UK (Conole et al., 2008; Laurillard, 2002; Sharpe et al., 2010). The third project was the Australian Universities Teaching Council (AUTC) Learning Design project based at Wollongong University (Herrington and Oliver, 2000) and the fourth project was the "Learning Activity Management System" (LAMS) at Macquarie University in Australia led by James Dalziel (Dalziel, 2003).

Learning design or design patterns as described by MOR et al. (2014) and several authors mentioned before, can provide educational guidance based on effective practice informed by theory. However, the challenge posed by learning analytics in the educational sector is interpreting the datasets against pedagogical outcomes and context. This is when learning design can be used to contextualise the pedagogic design of a unit of study and then later evaluate it against the data captured via a VLE (Dawnson et al., 2010; Lockyer et al., 2013)

In this paper, we explore how the CEG Learning Design Framework used in the design and delivery of the Online MA Photography at Falmouth University was implemented and how the interpretation of learning analytics from that programme can inform its design.

\section{Online MA Photography Programme}

Validated in 2016, the MA Photography Programme is a part taught, part research-based programme, delivered over two years, with three semesters or study blocks per year. 30 credits are delivered per study block, which comprises 
twelve weeks of teaching, followed by a 3-4 week assessment period during which students work on their research projects independently and complete an optional task in preparation for the next module.

There are 300 notional learning hours per study block. The Final Major Project at the end of the programme is a 60 credit module, delivered over two study blocks. This is primarily a period of independent research and is designed differently to modules $1-4$, therefore not making it relevant to this study.

The overall objective of the first module, Positions and Practice, is to allow students to locate and critically examine their practice within the broad territory of professional contemporary photography, and establish a clear point of departure for the practice-based research project they will undertake for the duration of the programme. A portfolio of practice, a (pre-recorded) oral presentation, and a research project proposal are summatively assessed at the end of the module.

Modules 2, 3 and 4 are designed in a similar way and have similar summative assessments: a portfolio of practice, submission of an ongoing critical research journal (weblog), and a reflective and contextual piece of work - either a written critical review of practice or an oral presentation. Although each looks at contemporary photography from a distinct perspective, students' research projects are central to each of these modules: Informing Contexts requires students to engage with the critical aspects of their practice; Surfaces and Strategies looks at practical methodologies in making and resolving work; Sustainable Prospects allows students to locate appropriate professional contexts, audiences and ways of disseminating practical work (McLeod, 2019).

Figure 2 shows the book-end structure of the modules with the first and last modules being fixed and the other three modules rotating depending on the cohort.

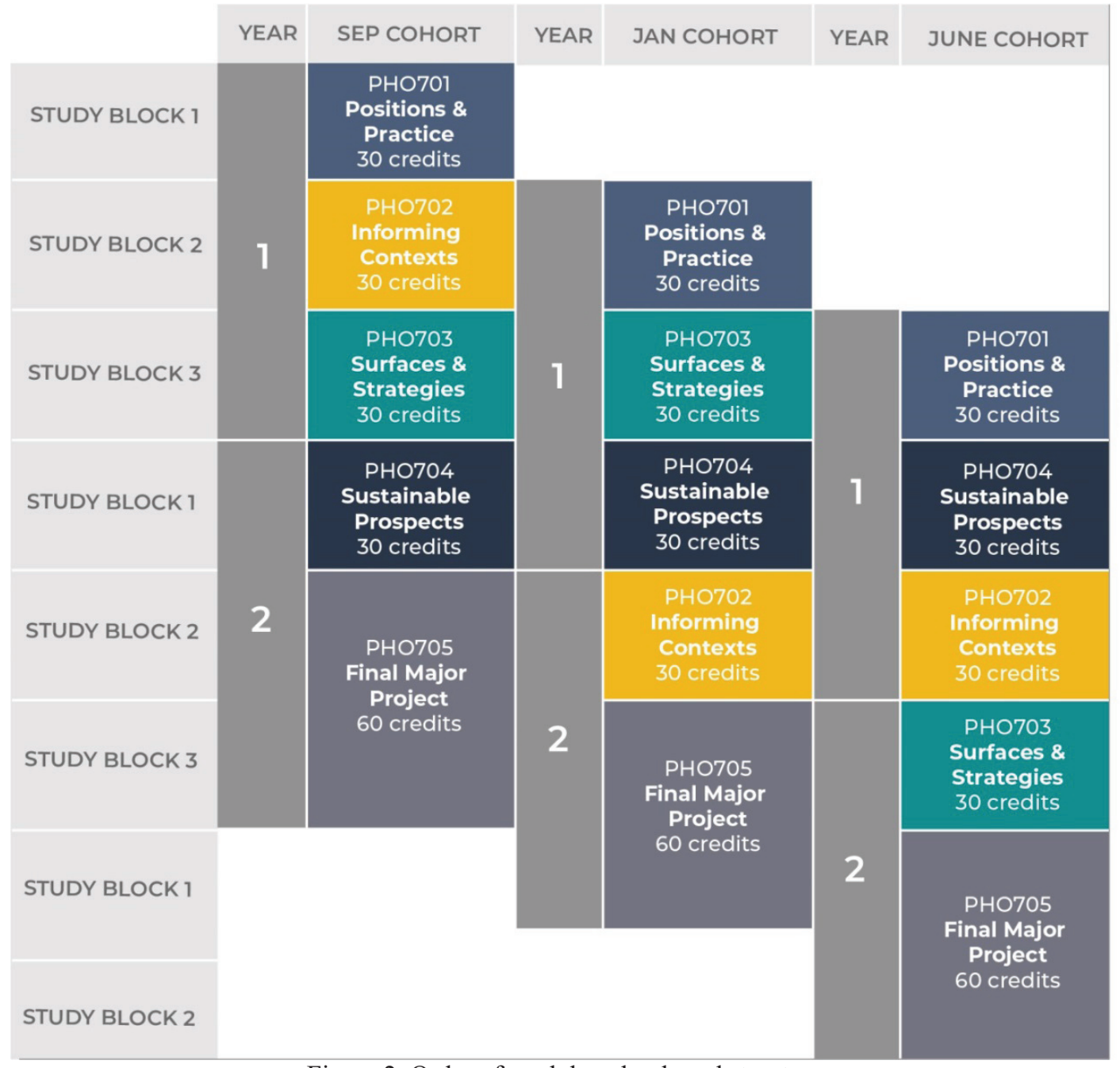

Figure 2. Order of modules - book-end structure. 


\section{Methodology}

This study was primarily a quantitative study with a qualitative element to supplement the data collected. Based on the CEG Learning Design Framework, we investigated how learning analytics could help us evaluate the delivery of the programme. The quantitative research explored student engagement with online activities that promoted low-order cognitive skills (i.e. watching videos, reading materials and listening to podcasts) as well as high-order cognitive skills (i.e. participating in online forums and webinars). Engagement with low-order cognitive skills was defined as the number of views on content pages associated with videos, readings and podcasts. Engagement with high-order cognitive skills was defined as number of posts in forums and participations in webinars.

Anonymised data was collected from 33 students from the three cohorts that had completed all the first 4 modules of the Online MA in Photography at Falmouth University. As explained in the previous section, each week was delivered in five steps: introduction, guided practice, challenge activity, reflection and webinar. Three types of data were collected from Canvas: number of views on content pages; number of posts in forums and participation in webinars; and final grade per student per module (Canvas, 2019).

The qualitative research was carried out as a focus group of 1-hour duration during the face to face Photography Symposium at Falmouth University in 2019.

The study was conducted according to a research protocol approved by the Falmouth Research Ethics Committee (Application reference REC 18 17).

\section{Results}

\subsection{Quantitative Research}

A dataset of over 80,000 entries was analysed. To calculate associations from the data collected, two independent variables were identified: number of views on content pages and number of posts in forums and participation in webinars. The dependant variable was the average final grade of each student in all four modules. The data from each variable was grouped and the mean for each student per variable was created.

As presented in Figures 3,4,5 and 6 below, there is weak evidence of an association between average overall mark in all modules and the level of engagement with self-directed content $(\mathrm{P}=0.0187)$. There is also weak evidence of an association between average overall mark in all modules and the level of engagement in collaborative activities $(\mathrm{P}<$ 0.0528).

Linear regression was used to assess the effectiveness of the engagement with different aspects of the online programme in relation to the student performance in the modules. After taking into account the average scores of the students that completed all 4 modules, there is marginal evidence of an increase in the overall mark in all modules as the number of views on content pages increases. There is also marginal evidence of an increase in the overall mark in all modules as the number of posts in forums and participation in webinars increases.

\begin{tabular}{|c|c|c|c|c|c|c|}
\hline \multicolumn{2}{|c|}{ coefficient } & \multicolumn{2}{|c|}{ std. } & ratio & \multicolumn{2}{|l|}{ p-value } \\
\hline 60.488 & 60.4883 & \multicolumn{2}{|c|}{1.54466} & 39.16 & $1.16 e-026$ & $* * *$ \\
\hline ViewsT & 0.00138527 & \multicolumn{2}{|c|}{0.000556036} & 2.491 & 0.0187 & $* *$ \\
\hline Mean dependent var & \multicolumn{2}{|c|}{63.80806} & \multicolumn{2}{|c|}{ S.D. dependent var } & \multicolumn{2}{|l|}{4.712255} \\
\hline Sum squared resid & \multicolumn{2}{|c|}{548.7202} & \multicolumn{2}{|c|}{ S.E. of regression } & \multicolumn{2}{|l|}{4.349872} \\
\hline R-squared & \multicolumn{2}{|c|}{0.176294} & \multicolumn{2}{|c|}{ Adjusted R-squared } & \multicolumn{2}{|l|}{0.147891} \\
\hline$E(1,29)$ & \multicolumn{2}{|c|}{6.206751} & \multicolumn{2}{|c|}{ P-value (F) } & \multicolumn{2}{|l|}{0.018696} \\
\hline Log-likelihood & \multicolumn{2}{|c|}{-88.52792} & \multicolumn{2}{|c|}{ Akaike criterion } & \multicolumn{2}{|l|}{181.0558} \\
\hline Schwarz criterion & \multicolumn{2}{|c|}{183.9238} & \multicolumn{2}{|c|}{ Hannan-Quinn } & \multicolumn{2}{|l|}{181.9907} \\
\hline
\end{tabular}

Figure 3. Report - Weak evidence of an association between average overall mark in all modules and the level of engagement with self-directed content $(\mathrm{P}=0.0187)$ 


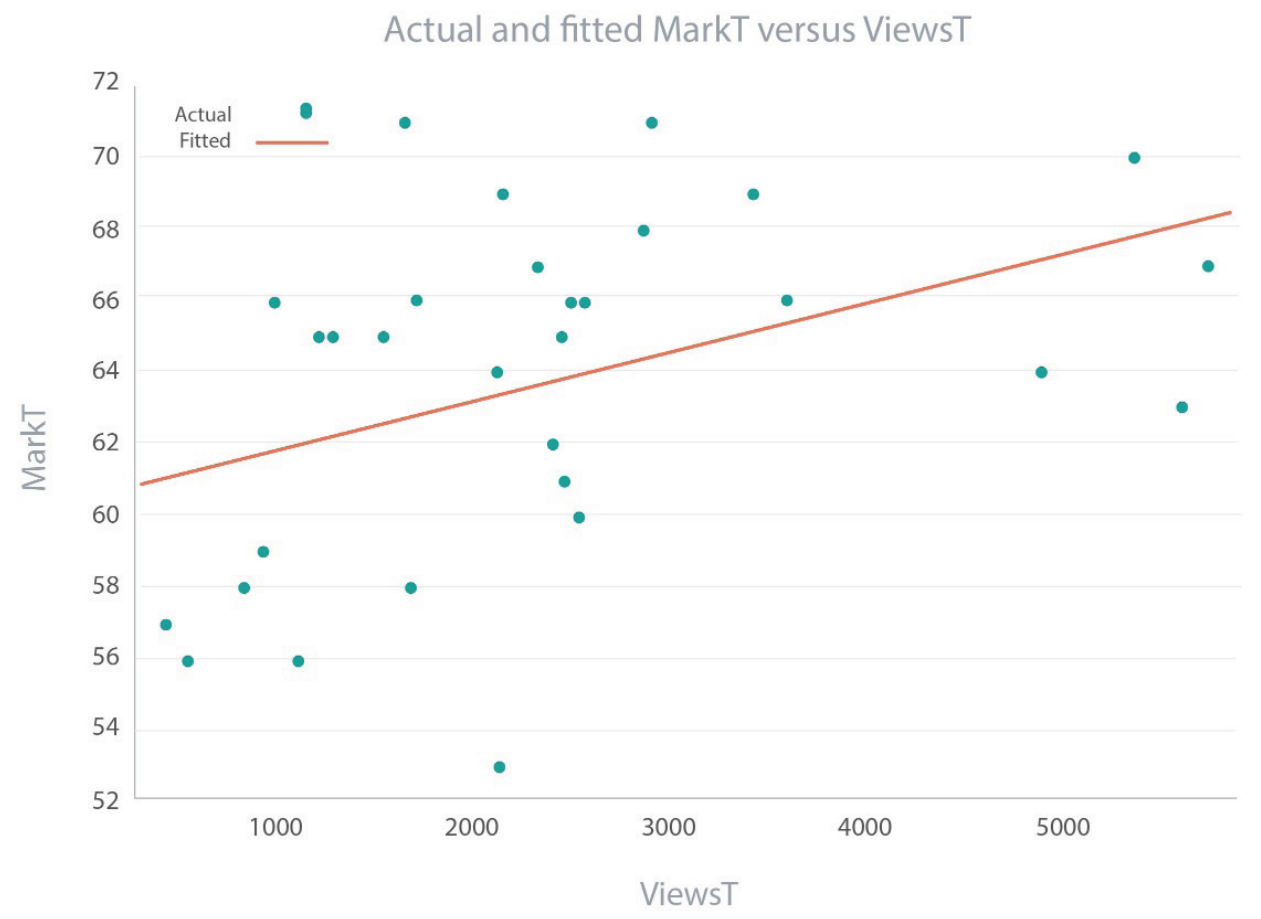

Figure 4. Graph - Weak evidence of an association between average overall mark in all modules and the level of engagement with self-directed content $(\mathrm{P}=0.0187)$

\begin{tabular}{|c|c|c|c|c|c|}
\hline & coefficient & std. error & t-ratio & p-value & \\
\hline const & 61.7705 & 1.29140 & 47.83 & $3.83 e-029$ & 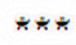 \\
\hline ParticipationT & 0.00952150 & 0.00471495 & 2.019 & 0.0528 & $*$ \\
\hline Mean dependent var & 63.80806 & S.D. depende & $t$ var & 4.712255 & \\
\hline Sum squared resid & 584.0319 & S.E. of regr & ssion & 4.487653 & \\
\hline R-squared & 0.123287 & Adjusted $\mathrm{R}-\mathrm{s}$ & uared & 0.093055 & \\
\hline$E(1,29)$ & 4.078082 & P-value (F) & & 0.052770 & \\
\hline Log-likelihood & -89.49460 & Akaike crite & ion & 182.9892 & \\
\hline Schwarz criterion & 185.8572 & Hannan-Quinn & & 183.9241 & \\
\hline
\end{tabular}

Figure 5. Report - Weak evidence of an association between average overall mark in all modules and the level of engagement in collaborative activities $(\mathrm{P}<0.0528)$ 


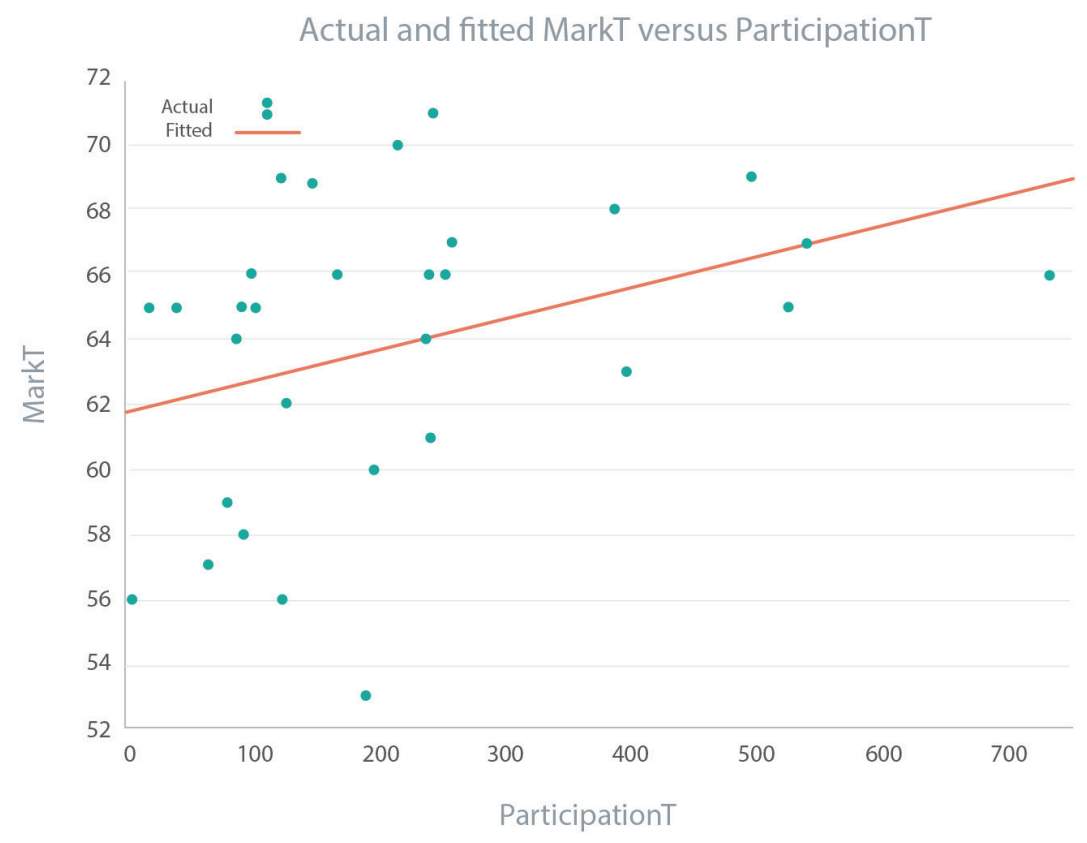

Figure 6. Weak evidence of an association between average overall mark in all modules and the level of engagement in collaborative activities $(\mathrm{P}<0.0528)$

\subsection{Qualitative Research}

A focus group of 1-hour duration was carried out during the face to face Photography Symposium with students from different cohorts at Falmouth University in 2019. Twelve students were invited to participate and six students took part in the focus groups. Three of these students had completed the MA Photography and three students were working on the Final Major Project.

Students were provided with refreshments but no other incentive was provided to recruit participants into the focus group. Qualitative data was analysed thematically. The focus group was recorded and transcribed by an external person who had not been involved in the design or teaching of the programme or the original design of the research study.

Three major themes emerged from the qualitative element to this study:

1. Weekly forums and webinars;

2. Self-directed learning materials;

3. Learning design and support.

Weekly forums and webinars

Weekly forums were generally regarded as both challenging and difficult at times for students if they involved teamwork. Students felt that working full time was a key factor for their engagement with structured online discussions that required planned group work.

Students thought it would be better if the groups were already allocated by the tutor rather than self-selected:

"I found it difficult as well because when I had to work collaboratively, I was the only one that worked full time..."

"Collaboration was a bit of a challenge because it depended on who you needed to collaborate with"

Weekly forums and group work was also described as opportunities to develop professional skills:

"It was challenging because sometimes you would get frustrated. But it also sets you up for real life because if you are collaborating with someone on a personal project then you need to be able to collaborate and negotiate roles, etc.." 
Weekly webinars with the online tutor were regarded as a support network rather than a learning collaborative channel. Students seem to have made an effort to attend their weekly webinars and seem to have gained a lot out of it:

"I think that the webinars weren't so much of a collaboration; more kind of a support network. With collaboration you're reliant upon other people feeding in, whereas with the webinar, you're there to support and be supported."

"I think possibly the collaboration that took place within our webinars was more successful than giving us the same task as an activity. I didn't miss a webinar: it was so useful to me. However, some of the other collaborations, for me, were just... well they were hard work!"

Students also reported having difficulties attending webinars. They suggested having a mix of morning and evening sessions to make it easier fit working schedules.

Students reported having difficulty with the amount of time allocated for tutor supervision during the Final Major Project (FMP).

"I think the FMP is really tricky anyways ... you only have 3.5 hours supervision anyway..."

Self-directed learning materials

Students identified engagement with self-directed learning materials as important. However, they all agreed it requires discipline and planning, especially when working full time.

Having a support community during the programme even during those periods of self-directed learning was identified as essential. Students also reported wanting a mixture of readings and podcasts which they could download and access while commuting.

"Sometimes it's really difficult to fit your schedule into the course because some weeks are a lot busier than others."

"It was also nice to know that those weeks that you were having a total 'nightmare' there was always a community there that you could go 'oh my god' help me!'."

"In terms of readings I would like to say that it would be nice to have more audio books, at least for me, this makes it really more flexible. When you don't have a lot of time for your own practice, I can spend time while commuting to do the readings."

Learning Design and support

Students discussed at length how the order of modules influences their learning experience. As mentioned previously, the five modules in the Photography Programme can be taken following a book-end structure with the first and last modules being fixed and the other three modules rotating depending on the cohort.

"I think that's the only issue with the course. The sequence you take them is not the same for everybody. And as we've seen, one sequence is a lot better than other sequences."

Some students reported having difficulty at the beginning of the programme due to their lack of pre knowledge in the area of Photography. They suggested having a pre-assessment at the beginning of the programme to guide their learning experience.

"I think it depended on where you're coming from. If you've done a BA in Photography before, I think you've got a different starting point, but if you haven't done any academic study in the subject before-it's quite a lot of work."

Students highlighted concerns that accessing library resources was difficult and not always reliable.

"When I went looking for materials, half of the things you couldn't get through the electronic resources online. It seemed very limited."

\section{Discussion}

The results of the learning analytics in this study suggest that engagement with low-end cognitive activities (self-directed activities) and potentially high-order cognitive activities (collaborative activities) may be good predictors of student performance (Bloom, 1956). A few studies have also suggested that engagement with online forums are related to higher course performance (Kent et al., 2016).

The qualitative analysis carried out in this study has been key to further assess the student experience in the delivery of the Photography Programme. The use of collaborative activities in the form of forums and webinars were unpacked and discussed in detail during the focus group highlighting the importance of providing more flexibility and more time for tutor-student support during the Final Major Project. 
According to student feedback, the amount of weekly self-directed activities should be revised using a mix of media: readings and podcasts. There is evidence that suggests learners are often biased in how they perceive and select new materials to learn. Therefore, highlighting the key and most important weekly points to cover would be encouraged (Gureckis \& Markant, 2012).

Learning pathways were also discussed among the students as having a major impact in their learning experience. However, very little research has been done to establish how module based qualifications serves students with different backgrounds and the impact of student choices on progression through qualification (Edwards \& Gaved, 2019). Further research in this area ought to be carried out to understand the student experience on diverse module pathways informing learning design.

Pre-course attitudes have also shown some predictive power on course grades among online students as described by (Perera et al., 2017). Their results suggest that exploratory-based learning may be more encouraging to online students due to their pre-existing attitudes. It would be interesting to find out more about students' attitude towards Photography before starting the MA Photography.

This research takes the first step to analysing the effect on student learning of elements implicit in the pedagogic design of online programmes at Falmouth University. This research highlights the importance of interpreting learning analytics within the context of a learning design framework in order to test learning design assumptions with actual student interaction data and student feedback.

A limitation of this study is that this project was relatively small and therefore provides no information about the scalability of the learning design approach. This will need to be explored in further studies. We will continue to analyse these effects throughout the modules of the online MA programmes at Falmouth University, and plan to expand the analysis over other such programmes and in other disciplines.

\section{Conclusion}

The outcomes from this research provide empirical evidence to support learning design practice in the growing field of online postgraduate education in higher education. This study represents one of the first attempts to introduce educational analytics and student feedback within the context of a clear pedagogic framework allowing the CEG learning design framework to be evaluated in context.

The results suggest there is weak evidence of an association between average overall mark in all modules and the level of engagement with self-directed content $(\mathrm{P}=0.0187)$. There is also weak evidence of an association between average overall mark in all modules and the level of engagement in collaborative activities $(\mathrm{P}<0.0528)$.

This paper explores students' perceptions and behaviour of online learning, within the Postgraduate Photography Programme and also within the wider online learning curriculum design. It has demonstrated that learning analytics can be used to provide some indication of student engagement but further learning insights need to be captured from the students voice to effectively assess the learning experience.

Careful consideration should be given to the learning design process of online learning in order to ensure an effective balance between collaborative and self-directed activities. Learning Design tools such as the CEG Pedagogic Framework may help in the process informed by student feedback. Careful attention and further research needs to be carried out in relation to the structure of the online learning experience particularly around learning pathways and sequence of learning.

\section{Acknowledgements}

The authors would like to thank Mike Pierre, E-learning Developer at CEG Digital for his technical support during the data mining process. The authors would also like to thank Annie Priddey, Student Advisor, for her support during the Focus Group.

\section{Competing interests}

The authors declare that they have no competing interests.

\section{References}

Anderson, T. \& Dron, J. (2010). Three generations of distance education pedagogy. The International Review of Research in Open \& Distance Learning, 12(3), 80-97. https://doi.org/10.19173/irrodl.v12i3.890

Astin, A. W. (1993). Changing course: Ten years of tracking online education in the United States. Babson Park, MA: Babson Survey Research Group. 
Bates, A. W. (2005). Technology, e-learning \& distance education. New York: Routledge.

Bloom B. (1956). Taxonomy of Educational Objectives, The Classification of Educational Goals, Handbook I: Cognitive Domain. UK: Longman Group.

Bonk, C. J., Graham, C. R., Cross, J. \& Moore, M. G. (2005). The handbook of blended learning: Global perspectives, local designs. San Francisco: Pfeiffer.

Cabrera, A. F., Crissman, J. L., Bernal, E. M., Nora, A., Terenzini, P. T. \& Pascarella, E. T. (2002). Collaborative learning: Its impact on college students development \& diversity, Journal of College Student Development, 43(1), 20-34.

Canvas Instructure (2019). Retrieved from https://www.instructure.com/

Citigroup (2017). Back to Basics: Is Education Fit For The Future?

Conole, G., Brasher, A., Cross, S., Weller, M., Clark, P. \& Culver, J. (2008). Visualising learning design to foster \& support good practice \& creativity, Educational Media International, 45(3), $177-194$. https://doi.org/10.1080/09523980802284168

Course Designs Sprint Framework - CoDesignS (2019). Retrieved from https://codesignssite.wordpress.com/

Dalziel, J. (2003). Implementing Learning Design: The Learning Activity Management System (LAMS). In: Crisp, G, Thiele, D, Scholten, I, Barker, S \& Baron, J (Eds.) Interact, Integrate, Impact: Proceedings of the 20th Annual Conference of the Australasian Society for Computers in Learning in Tertiary Education. Adelaide, 7-10 December 2003.

Dalziel, J. (eds) (2016). Learning Design: Conceptualizing a Framework for Teaching \& Learning Online. Routledge.

Dawson, S., Heathcote, E. \& Poole, G. (2010). Harnessing ICT potential: The adoption \& analysis of ICT systems for enhancing the student learning experience, International Journal of Educational Management, 24(2), 116-128. https://doi.org/10.1108/09513541011020936

De Freitas, S. I., Morgan, J. \& Gibson, D. (2015). Will MOOCs transform learning \& teaching in Higher Education? Engagement \& course retention in online learning provision, British Journal of Educational Technology, 46(3), 455-471. https://doi.org/10.1111/bjet.12268

Dumford \& Miller (2018). Online learning in higher education: exploring advantages \& disadvantages for engagement, Journal of Computers in Higher Education, 30, $452-465$. https://doi.org/10.1007/s12528-018-9179-z

Edward, C. \& Gaved, M. (2019). Analysing student study choices to qualification: which study routes are best? In Proceedings of the ALT Annual Conference 2019: University of Edinburgh, UK, 3-5 September.

Garrison, D. R. (1985) Three generations of technological innovations in distance education, Distance Education, 6(2), 235-241. https://doi.org/10.1080/0158791850060208

Gureckis, TM \& Markant DB (2012). Self-Directed Learning: A Cognitive \& Computational Perspective, Perspectives on Psychological Science, 7(5), 464-81. https://doi.org/10.1177\%2F1745691612454304

Harasim, L. (2017). Learning Theory \& Online Technologies. New York: Routledge.

Herrington, J., Oliver, R. (2000). An instructional design framework for authentic learning environments, Educational Technology Research \& Development, 48(3), 23-48, 26. https://doi.org/10.1007/BF02319856

Holmberg, B. (2005). Theory \& practice of distance education. London: Routledge.

IMS GLC (2003). Learning Design specification, Retrieved from http://www.imsglobal.org/learningdesign/

Jaggars, S. (2013). Choosing Between Online \& Face-to-Face Courses: Community College Student Voices, Community College Research Centre.

Jennings, C. (2013). 70:20:10 - A Framework for High Performance Development Practices. Retrieved from http://charles-jennings.blogspot.co.uk/2013/06/702010-framework-for-high-performance.html

Jung, Y. \& Lee, J. (2018). Learning engagement \& persistence in massive open online courses (MOOCs), Computers \& Education, 122, 9-22. https://doi.org/10.1016/j.compedu.2018.02.013

Keegan, D. (2013). Foundations of distance education. London: Routledge. 
Kent, C., Laslo, E. \& Rafaeli, S. (2016). Interactivity in online discussions \& learning outcomes, Computers \& Education, 97, 116-128. https://doi.org/10.1016/j.compedu.2016.03.002.

Kolb, D. A. (1984). Experiential learning: Experience as the source of learning \& development (Vol. 1). Englewood Cliffs. NJ: Prentice-Hall.

Kuh, G. D. (2001). The National Survey of Student Engagement: Conceptual framework \& overview of psychometric properties, Bloominghton, IN: Indiana University, Center for Postsecondary Research.

Koper, E J R (2001). Modelling Units of Study from a Pedagogical Perspective: The pedagogical metamodel behind EML. Heerlen: Open Universiteit Nederland, Retrieved http://eml.ou.nl/introduction/docs/ped-metamodel.pdf

Laurillard, D. (2002). Rethinking University Teaching: A Conversational Framework for the Effective Use of Learning Technologies (2nd Edn). London: RoutledgeFalmer. http://dx.doi.org/10.4324/9780203304846

Laurillard, D. (2012). Teaching as a Design Science. New York: Routledge.

Lockyer, L., Heathcote, E. \& Dawson, S. (2013). Informing Pedagogical Action: Aligning Learning Analytics With Learning Design, American Behavioral Scientist, $1439-1459$. https://doi.org/10.1177/0002764213479367

Lombardo, M M., Eichinger, R W. (1996). The Career Architect Development Planner (1st edition). Minneapolis: Lominger. p. iv. ISBN 0-9655712-1-1.

Martin, F., Wang, C. \& Sadaf, A. (2018). Student perception of helpfulness of facilitation strategies that enhance instructor presence, connectedness, engagement \& learning in online courses, The Internet \& Higher Education, 37, 52-65. http://dx.doi.org/10.1016/j.iheduc.2018.01.003

Masterman, E. (2009). Activity Theory \& the Design of Pedagogic Planning Tools. In L. Lockyer, S. Bennett, S. Agostinho, \& B. Harper (Eds.), Handbook of Research on Learning Design \& Learning Objects: Issues, Applications \& Technologies (pp. 209-227). Hershey, PA: IGI Global. https://doi.org/10.4018/978-1-59904-861-1.ch009

Mayer, R. E. (2019). Thirty years of research on online learning, Applied Cognitive Psychology, 33(2), 152-159. https://doi.org/10.1002/acp.3482

McLeod, G. (2019). Rephotography for photographers: discussing methodological compromises by post-graduate online learners of photography, Journal of Visual Literacy. Retrieved from https://www.tandfonline.com/doi/full/10.1080/1051144X.2018.1564606

Lockyer, S. Bennet, S. Agostinho \& B. Harper (Eds.), Handbook of research on learning design \& learning objects issues applications \& technologies (Vol. 1, pp. 209-227). Hershey, PA: Information Science Reference.

Means, B., Bakia, M. \& Murphy, R. (2014). Learning online: What research tells us about whether, when \& how. New York: Routledge.

Mor,Y., Mellar, H., Warburton, S., \& Niall Winters (Eds.) (2014). Practical Design Patterns for Teaching \& Learning with Technology, Sense Publications

Morton, C., Saleh, S., Smith, S., Hemani, A., Ameen, A., Taylor, B. \& Toro-Troconis, M. (2016). Blended learning: How can we optimise undergraduate student engagement?, BMC Medical Education, 16(195), https://oi: 10.1186/s12909-016-0716-z

Omrod, J. E. (2011). Human learning (6th ed.). Upper Saddle River, NJ: Pearson.

Panigrahi, R., Srivastava, P. R. \& Sharma, D. (2018). Online learning: Adoption, continuance \& learning outcome A review of literature, International Journal of Information Management, 43, 1-14. https://doi.org/10.1016/j.ijinfomgt.2018.05.005

Pascarella, E. T. \& Terenzini, P. T. (2005). How college affects students: A third decade of research (Vol. 2). San Francisco, CA: Jossey-Bass.

Perera, V., Mead, C., Buxner, S., Lopatto, D., Horodyskyj, L., Semken, S. \& Anbar, Ariel D. (2017). Students in Fully Online Programs Report More Positive Attitudes toward Science than Students in Traditional, In-Person Programs. CEG - Life Sciences Education. Winter. 16:ar60, 1-14. 
Rienties, B. \& Toetenel, L. (2016). The impact of learning design on student behaviour, satisfaction \& performance: a cross-institutional comparison across 151 modules, Computers in Human Behavior, 60, 333-341. https://doi.org/10.1016/j.chb.2016.02.074

Robinson, C. C. \& Hullinger, H. (2008). New benchmarks in higher education: Student engagement in online learning, Journal of Education for Business, 82(2), 101-108. https://doi.org/10.3200/JOEB.84.2.101-109

Roll, I., Russell, D. M. \& Gasevic, D. (2018). Learning at scale, International Journal of Artificial Intelligence in Education, 28(4), 471-477. https://doi.org/10.1007/s40593-018-0170-7

Sharpe, R., Beetham, H., De Freitas, S. (2010). Rethinking Learning for a Digital Age: How Learners are Shapping their Own Experiences, New York: Routledge, 2010.

Siemens, G. (2013). Learning Analytics: The Emergence of a Discipline, American Behavioral Scientist, 57(10), 1380-1400. https://doi.org/10.1177/0002764213498851

Simpson, O. (2018). Supporting students in online, open \& distance learning. London: Routledge.

Stephenson, J. (2018). Teaching \& learning online: new pedagogies for new technologies. New York: Routledge.

Taylor, J. C. (2001). Fifth generation distance education. Instructional Science \& Technology, 4(1), 1-14. http://eprints.usq.edu.au/id/eprint/136

Thurmond, V. \& Wambach, K. (2004). Understanding interactions in distance education: A review of the literature, International Journal of Instructional Technology \& Distance Learning, 1, 9-33. http://www.itdl.org/journal/Jan_04/article02.htm

Toetenel, L., Rienties, B. (2016). Analysing 157 learning designs using learning analytic approaches as a means to evaluate the impact of pedagogical decision making. British Journal of Educational Technology, 47(5), 981-992. https://doi.org/10.1111/bjet.12423.

Toro-Troconis, M. \& Aleksiev, A. (2018). Does Learning Design have an effect on student performance? - Aligning Learning Design with Learning Analytics. In Proceedings of the ALT Annual Conference 2018: University of Manchester, UK, 11-13 September.

Toro-Troconis, M., Bridson, J-M., Halawa, H., Prescott, D. \& Edwards, S. (2016). Course Design Sprint Framework (CoDesignS). In Proceedings of the ALT Annual Conference 2016, University of Warwick, UK, 6-8 September.

Toro-Troconis, M. (2015). Why we should pay more attention to E-learning. Journal of Health Specialties, 3(4). 191-197 https://doi.org/10.4103/1658-600X.166499.

UN (2015). Draft Preliminary Report Concerning the Preparation of a Global Convention on the Recognition of Higher Education Qualifications, Paris.

Universities UK (2018). Flexible Learning. The current State of Play in UK Higher Education.

Wong, J., Baars, M., Davis, D., Van Der Zee, T., Houben, G-J. \& Paas, F. (2018). Supporting self-regulated learning in online learning environments \& MOOCs: A systematic review. Journal of Human-Computer Interaction, 35(4-5), 356-373. https://doi.org/10.1080/10447318.2018.1543084

Zhang, D. \& Nunamaker, J. F. (2003). Powering e-learning in the new millennium: an overview of e-learning \& enabling technology. Information systems frontiers, 5(2), 207-218. https://doi.org/10.1023/A:1022609809036 